\title{
Hvornår og hvordan straffer vi skattesnydere?
}

\author{
Af Gorm Toftegaard Nielsen ${ }^{1}$
}

\begin{abstract}
This article provides an overview of developments in Danish law on tax evasion over the last 50 years. It is shown that tax authorities have preferred to deal with such cases on their own, and that the criminal law community has had little interest in the subject. There is a discussion of the extent to which accessories to the tax evasion of others should be punished, for example, a taxpayer's accountant or those who buy goods or services without paying proper tax. There is also a discussion of whether punishment should be aimed at persons or at their businesses. Finally, there are references to some new rules, e.g., payment over the internet, which should allow for better control. ${ }^{*}$
\end{abstract}

\section{Strafværdigheden}

Det er påfaldende, at skattesnyderi spiller en ringe rolle inden for nordisk strafferet, selv om skattesnyderiet efter de store beløb, det handler om, er en endog meget væsentlig del af den økonomiske kriminalitet. Skyldes vores manglende interesse for dette emne, at det er for svært for strafferetsfolk, der har det bedre med voldtægt og tyveri? Eller skyldes den, at vi af ideologiske grunde ikke synes skattesnyderi er en alvorlig kriminalitet, som fortjener vores interesse. Da jeg foreslog arrangørerne af Kriminalistmødet dette emne, fik jeg et positivt svar med bl.a. følgende begrundelse: »... temaet åpner for grunnleggende spørgsmål, herunder hva vi skal bruke strafferettsapparatet til - og hva som bør høre under (den øvrige) forvaltningens sanksjonskompetanse.« Havde jeg foreslået socialbedrageri, havde jeg næppe fået dette svar. Man kan måske formulere spørgsmålet sådan: Hvorfor behandler vi et socialbedrageri til $100.000 \mathrm{kr}$. som langt mere strafværdigt end et skattesvig til $100.000 \mathrm{kr}$. Skattesvig op til $250.000 \mathrm{kr}$. straffes i Danmark efter skattelovgivningen med bøde, mens socialbedrageri til $10.000 \mathrm{kr}$. straffes med fængselsstraf (betinget). Skattesvig skal andrage $500.000 \mathrm{kr}$. før der straffes efter straffeloven, mens ethvert socialbedrageri straffes efter straffeloven (dog med en bagatelgrænse på 5.000 kr.).

* Title in English: How and when tax cheats are punished. 
Når man diskuterer disse forhold med skattefolk, får man ofte en lang redegørelse for, hvor mange penge, der frivilligt indbetales til SKAT og hvor lille problemet med skattesnyderi er. Man hører aldrig tilsvarende analyser af, hvor lille et beløb socialt bedrageri udgør i forhold til den samlede sum af socialydelser. Det er da heller ikke normalt et argument for ikke at straffe, at forbrydelsen har et ringe omfang i forhold til den tilsvarende lovlige adfærd.

At der ikke er tale om et nyt fænomen ses af referaterne fra det fjerde nordiske kriminalistmøde i 1957 i Oslo, hvor skattestrafferetten var på programmet, jf. NTFK 1957 s. 1-51. Den norske højesteretsdommer O.C. Gundersen understregede skattemyndighedernes uvilje mod at afgive sagerne til politi og anklagemyndighed, som var dårligt rustet til at behandle og procedere sagerne. Skatteyderne - eller rettere dem der nødigt ville yde - mødte modsat med meget kvalificerede specialister. Hans forslag var, at Norge indtil videre lod skat beholde sagerne. Først når det med nogen sikkerked kunne fastslås, at det var normalt også på dette område at overholde loven, kunne man overføre sagerne til politiet og anklagemyndigheden. Den danske politiadvokat Jørgen Smith redegjorde for sagernes behandling, herunder at de fleste sager blev afgjort af skattemyndighederne med bøder, men at skattevæsnet kunne vælge at overgive sagerne til retsvæsnet. Frihedsstraf kunne naturligvis kun idømmes af domstolene. Smith nævnte nogle sager med frihedsstraf, bl.a.: 20 dages hæfte for skattesvig til $10.000 \mathrm{kr}$. og 40 dage for $50.000 \mathrm{kr}$. Smith nævnte, at der i skattekontrolloven er en særlig bestemmelse om straf for den, der ved erhvervsmæssig bistand (typisk en revisor) hjælper skatteyderen med at snyde. Smith stillede ikke spørgsmål ved rimeligheden af at straffe skattesvig. Han udgav i øvrigt få år efter den første fremstilling af reglerne for og behandlingen af disse sager (Skatteunddragelser, efterbetaling og straf, Kbh. 1961). Inkeri Anttila anførte, at den almindelige opfattelse i Finland havde været, at skattesvig ikke kan sidestilles med »egentlig brottslighet« og at skattesnydere ikke er forbrydere i ordets normale forstand. Hans Thornstedt fra Sverige fandt det svært at bedømme disse overtrædelser pga. for lidt empirisk viden. Han mente, at en undersøgelse ville vise, at overtræderne i mange tilfælde havde »karaktärsdrag« eller andre egenskaber, som skilte dem fra den øvrige befolkning. Han troede derfor, at andre midler end det normale straffesystems vil være at foretrække.

Generelt havde landene et system, hvorefter den unddragne skat skulle efterbetales sammen med et beløb, der udgjorde det dobbelte eller mere af skatteunddragelsen.

Generelt var der altså i oplæggene - bortset fra det danske - en uvilje imod at bruge det almindelige straffesystem i disse sager. Argumenterne imod at bruge 
straffesager kan næppe tænkes anvendt på andre områder. Det naturlige er vel et system, hvor væsentlige pønale byrder bør pålægges som straf, mens mindre byrder f.eks. parkeringsafgift, kontrolgebyr for at snyde sig til transport o. lign. kan overlades til administrationen uden den almindelige straffeprocessuelle beskyttelse.

\section{Sagernes behandling}

Der har i Danmark været begrænset interesse i ud fra en strafferetlig synsvinkel at undersøge SKAT's behandling af straffesager. Undtagelsen er en licentiatafhandling: Mogens Moe: Administrative bøder, 1973, om de sager, hvor andre forvaltningsmyndigheder end politiet kunne udstede bødeforlæg, altså selv afslutte sagerne som straffesager uden politiets mellemkomst. Skattevæsnet var den væsentligste aktør på dette område. Moes konklusion var ret klar: Skattemyndighedernes sagsbehandling var klart ikke præget af den samme retssikkerhed som politiets og anklagemyndighedens sagsbehandling. Det er vel karakteristisk, at strafferetsfolk interesserede sig for politiets og anklagemyndighedens sagsbehandling, mens forvaltningsretsfolk ikke interesserer sig for selve håndhævelsen.

Ved behandlingen af skattesvig starter sagerne med SKAT's kontrolarbejde. SKAT har i denne forbindelse forskellige beføjelser. De to væsentligste er en udstrakt ret til uden retskendelse at foretage kontrolbesøg hos virksomheder for at tjekke deres oplysninger, og at forlange oplysninger fra de kontrollerede. Det er klart, at der her er et problem i forhold til straffeprocessen, da det er et fundamentalt princip i straffeprocessen, at politiet som udgangspunkt kun kan foretage ransagning efter dommerkendelse. Kan man så lade SKAT foretage alle undersøgelserne til en straffesag uden at overholde straffeprocessens regler, og når så alle beviserne er fremskaffet, at overgive sagen til politiet. Det andet problem er nok endnu større. Det er velkendt, at en sigtet i en straffesag ikke kan pålægges at inkriminere sig selv, men skal have at vide, at han ikke har pligt til at udtale sig, mens han i skattesagen som nævnt har pligt til at besvare spørgsmålene. Det er derfor centralt, hvornår sagerne overgives af SKAT til politiet, men beskyttelsen kan ofte indtræde tidligere. I Danmark blev dette problem løst ved lov nr. 442 af 9.9.2004 om retssikkerhed ved forvaltningens anvendelse af tvangsindgreb og oplysningspligter. Kort sagt kan forvaltningen ikke udnytte sine beføjelser, når SKAT har en vis mistanke om, at der foreligger skattesvig. Når denne mistanke foreligger skal SKAT altså have politiet til efter retskendelse at foretage ransagning. I Danmark er det SKAT, der står for hele ligningsarbejdet og altså størstedelen af sagens undersøgelse. Der er således ikke noget skattepoliti. Sagerne føres enten af Statsadvokaten for økonomisk kriminalitet eller lokale særlige afdelinger for økonomisk kriminalitet. 
Anklagerne vil i disse sager ofte stå over for særdeles skatteretskyndige forsvarere og have svært ved at matche deres juridiske kunnen. Det er derfor væsentligt, at anklageren har juridisk bistand fra SKAT, og helst den medarbejder, som har haft sagen. Der har i Danmark tidligere været en tradition for, at retten gav tilladelse til, at forvaltningens sagsbehandler kunne overvære retsmødet, også selv om han eventuel senere skulle bruges som vidne. Uden en sådan tilladelse er SKAT næsten nødt til at have en, som kender sagen særdeles godt, siddende i retten, og en anden med samme viden, som man, hvis det bliver nødvendigt, kan bruge som vidne. I de senere år har domstolene været tilbøjelige til at kræve, at den skattemedarbejder, der skal bruges som vidne, ikke har overværet nogen del af rettens behandling af sagen.

Det er karakteristisk, at skatteretsfolkene har deres egen litteratur og domssamling, som kun i meget begrænset omfang læses af anklagemyndighedens folk, ligesom det omvendte er tilfældet.

\section{Teorien}

Der er i Danmark kun begrænset litteratur om skattestrafferetten. Daværende lektor i strafferet Jan Pedersen udgav i 1989 sin disputats Skatteudnyttelse. Arbejdet var nok startet som et strafferetligt projekt, men bevægede sig i betydeligt grad over i skatteretten. Jan Pedersen forlod da også efterfølgende strafferetten og blev professor i Århus i skatteret. Han opstillede i afhandlingen en tredeling af skatteudnyttelserne:

1. skattetænkning,

2. skatteunddragelse og

3. skattesvig.

Alle ønsker vel at betale mindst muligt i skat og det er helt legitimt at disponere for at spare i skat. Man kan måske undre sig over, at store firmaer som Mc Donald og Coca Cola efter sigende aldrig har tjent en krone i Danmark, men det er svært at kontrollere om de køber for dyrt ind ved egne selskaber i skattely-lande (transfer-pricing). Det er jo rimelig let at drive dårlig forretning. Skattelettelser bruges endog direkte i lovgivningen som incitament for at antage arbejdskraft. Det er skattetænkning. Hvis loven overtrædes for at mindske beskatningen er det skatteunddragelse og kun i de groveste tilfælde er det skattesvig. Problemet er grænsen mellem 2 og 3.

Udgangspunktet for Jan Pedersens afhandling var Glistrup-sagen. Meget kort fortalt havde Danmarks nok mest kyndige skatteretsjurist Mogens Glistrup i sit 
advokatfirma oprettet en stribe selskaber, som klienter kunne låne penge hos og gennem en række transaktioner, herunder låneoptagelser og aktiesalg, opnå betydelige skattefradrag for renter. Klienterne betalte aldrig disse renter, men de blev bogført $i$ et exceptionelt kompliceret netværk af selskaber. Formelt kunne det hævdes, at alle relevante udgifter og indtægter var bogført. Glistrup havde angivet alle oplysningerne formelt korrekt til skattevæsnet. Systemet muliggjorde, at han ikke selv betalte nogen skat. Problemet var nok i betydelig grad, at det erklærede han frejdigt $i$ en radioudsendelse i 1971. Blandt flere skatteretskyndige var der nok enighed om, at der ikke var noget ulovligt i metoden, men den gav naturligvis regeringen store problemer. Glistrup oprettede sit eget politiske parti Fremskridtspartiet, som fik meget medvind i befolkningen også i stemmeurnerne. Glistrup endte efter 11 års retlig behandling med i Højesteret at blive idømt 3 års fængsel og en bøde på 1 mio. kr., Ugeskrift for Retsvæsen 1975 s. 388H. Højesteret fandt, at de nævnte dispositioner var uden erhvervsmæssig og økonomisk realitet. Afhandlingen behandler en række andre problemer, bl.a. spørgsmålet om, hvilken betydning det har, hvis skatte(sn)yderen har søgt sagkyndig rådgivning og f.eks. har disponeret efter råd fra en skattekyndig advokat. Jan Pedersen kritiserer, at domstolene i disse tilfælde har været meget tilbøjelige til at sige, at skatteyderen, der har fulgt sin professionelle rådgivers råd, har haft forsæt til skattesvig. Kan man virkelig opstille en formodning for, at den, der søger en advokats råd, har forsæt til svig?

I 2009 udgav Lasse Lund Madsen sin ph.d.afhandling Medvirken i erhvervsstrafferetten. I denne behandles s.368 ff. medvirken i skatte- og afgiftsstrafferetten. Forfatteren skelner mellem den spekulative skattesvig og primitiv skattesvig. Glistrup-sagen vedrørte den spekulative skattesvig, som altså i meget høj grad vedrører fortolkningen af den materielle skatteret. I sin afhandling behandler Lasse Lund Madsen den primitive skattesvig, primært det vi kalder sort arbejde.

\section{Medvirken}

En af de væsentligste forskelle på en forvaltningsretlig og en strafferetlig tilgang er, at forvaltningsretten primært henvender sig til adressaten, her skatteyderen. Strafferetten er (i Danmark) derimod præget af ønsket om at finde den eller de egentlige overtrædere.

Dette belyses bedst gennem straffelovens $§ 23$ :

»Den for en lovovertrædelse givne straffebestemmelse omfatter alle, der ved tilskyndelse, råd eller dåd har medvirket til gerningen ... 
Stk. 2. Straffen kan ... nedsættes for den, der medvirker til krænkelse af et særligt pligtforhold, men selv står uden for dette«.

Det udtrykkes altså klart, at strafansvaret ikke kun rammer adressaten for pligten, men enhver der er med til at tilsidesætte pligten og derved bidrager til den strafbare handling. Det følger af straffelovens $\S 2$, at $§ 23$ også gælder for overtrædelse af straffebestemmelser $i$ andre love end straffeloven, altså her overtrædelser af skattelovgivningens straffebestemmelser.

Til trods for denne klare retsstilling indeholder skattekontrolloven følgende:

»§13: Den, der med forsæt til at unddrage det offentlige skat, afgiver urigtige eller vildledende oplysninger til brug ved afgørelse af, om en person er undergivet skattepligt, eller til brug ved afgørelse af skatteansættelse eller skatteberegning, straffes for skattesvig med bøde eller fængsel indtil 1 år og 6 måneder, medmindre højere straf er forskyldt efter straffelovens $\S 289$. På samme måde straffes medvirken til skattesvig, jf. straffelovens $\S 23 . «$

Formuleringen afslører et typisk problem. Første punktum omfatter klart ikke blot skatteyderen (»om en person«), men også andre, der er med til at give forkerte oplysninger, f.eks.. en revisor. Denne lov er skrevet af skatteministeriets jurister, som har et begrænset kendskab til straffeloven og derfor tror, at det er nødvendigt at formulere revisors medvirken på den angivne måde. Formuleringen bliver let fortolket således, at medvirken kun er strafbar for den, der medvirker umiddelbart ved udfærdigelsen af selvangivelsen. Den bestemmelse, som skal sikre medvirkensansvar for skattesvig bliver altså fortolket som en begrænsning af medvirkensansvaret. For at undgå denne fortolkning har man i 1999 sat et nyt punktum ind i § 13, hvorefter straffelovens medvirkensregel også gælder i disse sager.

De 2 væsentligste former for medvirken er for det første den overfor omtalte rådgivningssituation, hvor lovens løsning er, at den, der rådgiver skatteyderen til en strafbar disposition kan straffes for medvirken, og at skatteyderen efter omstændighederne kan have handlet i den tro, at det var lovligt at følge det modtagne råd, og derfor skal frifindes. Den anden situation vedrører sort arbejde. Den, der udfører og tjener på arbejdet, men holder indtægten skjult for skattevæsnet, kan naturligvis straffes. Det spændende er, om den, der bestiller arbejdet, kan straffes.

Det er i Danmark ikke ualmindeligt, at nogen aftaler med den, der skal udføre et arbejde, at det er sort. Strafferetlig set er sort arbejde en svær størrelse. Den, der køber arbejdet, ser ikke sælgerens selvangivelse, og man kan naturligvis ikke straffe ham for ikke at have kontrolleret sælgerens selvangivelse. Risikoen for, at skattemyndighederne finder ud af, at sælgeren undlader at opgive indtægten er meget lille. Det er næsten umuligt for SKAT i noget videre omfang at registrere formodet sort arbejde og så gemme oplysningerne i mange måneder for at se, om det bliver oplyst i sælgerens regnskaber. Hvis der ikke er noget skriftligt materia- 
le, der viser at arbejdet er udført, er opdagelsesrisikoen særdeles ringe. Aftaler om sort arbejde indgås derfor ofte på den måde, at køberen siger, at han ikke behøver nogen kvittering og undertiden også, at han betaler med kontanter.

I Ugeskrift for Retsvæsen 1998B s. 336 ff. foreslog jeg, at man kunne indføre en pligt til, at personer der havde fået udført arbejde for et vist mindstebeløb, f.eks. 10.000 kr. skulle opbevare deres kvittering i 10 år. Den socialdemokratiske skatteminister mente, at det ville være urimeligt at lægge en sådan byrde på befolkningen. Han var øjensynligt ikke klar over, at de almindelige formueretlige regler bygger på, at borgerne får en kvittering for, at de har betalt og så gemmer kvitteringen, indtil fordringen efter de almindelige forældelsesregler ikke længere kan kræves betalt. Eller også havde han denne ret banale viden, men blot ønsket at finde et argument for ikke at kriminalisere køberen af sort arbejde.

I 1999 vedtog man bl.a. følgende bestemmelse om medvirken til skattesvig:

$\S 13 \mathrm{c}$. Den, der som led i virksomhed forsætligt udsteder en faktura med et urigtigt indhold eller udsteder anden urigtig dokumentation for levering eller aftagelse af varer eller ydelser, straffes med bøde eller fængsel indtil 1 år og 6 måneder, medmindre højere straf er forskyldt efter straffelovens $\S 289$, hvis dokumentationen er egnet til at blive anvendt som grundlag for opgørelsen af den skattepligtige indkomst.

I en note i Karnov (udarbejdet af en medarbejder fra SKAT) anføres, at hvis betingelserne efter $\S 13 \mathrm{c}$ er opfyldt, kan der alene straffes efter denne bestemmelse, og ikke evt. samtidig gøres ansvar gældende for medvirken til skattesvig efter $\S 13$. Der er tale om en noget speciel lovkoncipering. Man har en almindelig bestemmelse i straffelovens $\S 23$, som medfører, at både private og virksomheder kan straffes for medvirken til skattesvig. Man vedtager så en lovbestemmelse, så virksomheder efter denne kan straffes for deres medvirken til en andens skattesvig efter denne bestemmelse. Ved denne særlige bestemmelse om medvirken vil man tilsyneladende undgå, at virksomhederne kan straffes for almindelig medvirken til skattesvig. Altså tilsyneladende sikre sig, at de får en mildere dom. Samtidig må man fortolke reglen sådan, at private ikke kan straffes for forsætlig medvirken til skattesvig, hvad de ellers kunne efter $\S 13$, jf. straffelovens $\S 23$.

En sådan lovgivning kan kun tages som udtryk for, at skattemyndighederne absolut ikke ønsker mulighed for at straffe den, der køber sort arbejde. Og det sker vel at mærke i et samfund, hvor man er meget indstillet på at straffe hælere for at tjene på andres forbrydelser. Og at lovgiver enten deler uviljen mod at straffe købere af sort arbejde eller ikke har forstået, at når man vedtager en lovbestemmelse om straf for virksomheders medvirken, er der tale om at udelukke ansvaret for de private, der medvirker. Og det sker, selvom der i $§ 13$ netop står, at straffelovens $\S 23$ om medvirken gælder.

\section{Brug af selskabsansvar}

I Danmark er der i lovgivningen i meget udstrakt grad hjemmel til at straffe ikke blot fysiske personer, men også juridiske personer eller virksomheder. Dette gælder også straf efter skattelovgivningen. 
Ved indførelsen af kildeskat i 1970 kriminaliserede man for sen indbetaling af indeholdt kildeskat. Også her var der hjemmel for at straffe virksomheder. Men SKAT havde givetvis en klar uvilje mod dette af den simple grund, at de skyldige virksomheder ofte ikke havde penge til at betale bøden med. Man indførte i forening med rigsadvokaten en praksis, så tiltalen, hvis virksomhedens hovedaktionær også var direktør og daglig leder af virksomheden skulle tiltales personligt i stedet for virksomheden. Oprindeligt begrundede rigsadvokaten dette system med, at en virksomhedsindehaver, der både fik hele fortjenesten og som reelt bestemte enerådigt, ikke skulle slippe for strafansvar ved blot at lave et anpartsselskab el. lign. Som bekendt er det økonomiske ansvar for disse selskaber begrænset. Men det var mærkeligt nok ikke til hinder for en udbredt praksis for, at man kunne straffe direktøren for ikke at have indbetalt det beløb, der måske ikke fandtes i selskabet, og som han ikke personligt hæftede for. SKAT udvidede hovedaktionærbegrebet ganske kraftigt, så direktøren, der sammen med familien ejede 50 \%, var omfattet. I Ugeskrift for Retsvæsen 1980 s. 1016 fik Højesteret for første gang forelagt spørgsmålet om hovedaktionærtiltalen og forkastede den meget vide bestemmelse af hovedaktionæren. Tiltalte fik derfor alene den sædvanlige direktørbøde på $20 \%$. SKAT meldte ud, at sagen var helt speciel og uden præcedensvirkning. I SKAT's politianmeldelser blev derfor fastholdt den forkastede praksis og anklagemyndigheden fulgte SKAT, hvilket også gjaldt domstolene. Da Straffelovrådet afgav sin betænkning om juridiske personers bødeansvar (nr. 1289.1995) kritiserede rådet meget klart hele denne tiltalepraksis:

»Det forhold, at den pågældende eventuelt fuldt ud ejer det selskab, i hvilket overtrædelsen har fundet sted, kan i princippet ikke påvirke den strafferetlige bedømmelse af den pågældendes forhold til overtrædelsen. Dette må i almindelighed også gælde i de tilfælde, hvor selskabet efterfølgende måtte være gået konkurs« (s. 125)

I øvrigt anbefalede rådet, at der blev udstedt direktiver om valget af tiltalesubjekt. Rigsadvokaten udstedte derfor sin meddelelse nr. 5/1999 om valg af ansvarssubjekt i sager om virksomhedsansvar. I denne henviser rigsadvokaten til den nævnte passus fra Straffelovrådet og anfører:

»Det bør på denne baggrund ikke i sig selv tillægges betydning for ansvarsplaceringen, at den pågældende er enerådende i den virksomhed, i hvilken overtrædelsen har fundet sted. Dette gælder også, såfremt virksomheden efterfølgende måtte være gået konkurs.« (pkt. 2.2.1)

SKAT er formelt ikke underordnet rigsadvokaten og fortsatte sin praksis. Anklagemyndighedens ansatte skal naturligvis rette sig efter meddelelsen, der er en tje- 
nestebefaling. Men anklagerne fulgte traditionen og rettede sig efter anmeldelsen. Det fremgik af litteraturen skrevet af SKAT's medarbejdere, at SKAT havde fået lov til ikke at rette sig efter nævnte regel. Selv om denne netop var vendt mod SKAT's praksis. I 2010 meddelte rigsadvokaten mig til brug for en artikel, at man på et møde i juni 2004 havde accepteret, at SKAT's område ikke er omfattet af den ovenfor nævnte del af rigsadvokatens meddelelse. Til trods for, at den nævnte regel netop primært vedrørte SKAT's sager er der ikke foretaget nogen ændring af meddelelsen. Også på dette område er der tale om en noget speciel behandling af skattestraffesagerne.

\section{Fremtiden}

SKAT har for nylig fået en række nye regler/beføjelser i kampen mod sort arbejde. De kan kort angives:

- Du skal som privatperson betale regninger på 10.000 kr. eller derover digitalt. Ellers kan SKAT kræve, at du betaler, hvad håndværkeren/sælgeren snyder med i skat og moms.

- Varebiler, der vejer under 4 ton, på gule plader skal have synligt firmanavn eller logo og CVR-nummer. Udenlandske varebiler skal synligt i bilens forrude have dokumentation for deres registrering i RUT-registeret.

- SKAT må gerne gå ind på privat grund - i fx en have - og lave en kontrol af, om håndværkerne arbejder lovligt, hvis de fra vejen kan se, at der på grunden foregår byggeaktivitet (byggematerialer, stillads osv.). SKAT må ikke gå ind i din private bolig.

- Alle arbejdsudøvende skal kunne fremvise gyldigt ID. Danskere skal fremvise pas, kørekort eller andet med CPR-nummer. Udenlandske skal fremvise visum, arbejds- eller opholdstilladelse.

- Der skal skiltes tydeligt på alle byggepladser - også dem der foregår på privat grund - så man kan se, hvem der udfører arbejdet. Det vil sige et skilt med virksomhedens navn, CVR- eller RUT-nummer.

- Unge under 16 år må gerne arbejde for familie, venner og naboer og hjælpe med små opgaver uden at betale skat af lønnen.

- Folkepensionister må skattefrit tjene op til 10.000 kr. årligt ved at hjælpe til i private hjem.

Adgangen til privates haver har været gældende siden den 1.7.2012. Der var megen kritik af reglens indførelse. Det første år blev foretaget 247 kontrolbesøg. I de 3 o blev afsløret socialt bedrageri eller bedrageri over for arbejdsløshedskasserne. 
Der verserer 25 sager om sort arbejde. Og 50 sager afventer håndværkernes selvangivelse for at se, om de begår skattesvig. Netop dette viser, at indgrebet kan have en præventiv virkning, men når håndværkerne ved, at der har været kontrolbesøg, sørger de naturligvis for at selvangive indtægten ved det pågældende arbejde, så besøgene vil næppe resultere i mange straffesager.

På et andet område har den teknologiske udvikling givet SKAT bedre undersøgelsesmuligheder. Den meget udbredte brug af elektroniske kreditkort giver SKAT store muligheder for at finde ud af, hvornår en given person har været $\mathrm{i}$ landet. Det kan få meget væsentlig bevismæssig betydning i sager, hvor SKAT mener at der foreligger skattesvig, fordi en person ikke har angivet sig som skattepligtig i Danmark, selv om hans eller hendes forbindelse har været så stærk, at vedkommende er skattepligtig. En prominent sag har medført betydelig kritik af skat. En kendt model med betydelig indtægter blev frifundet med den begrundelse, at efter SKAT's nye fortolkning var hun ikke skattepligtig i Danmark. Landsretten henviste til, at den kendte den nye praksis pga. pressens offentliggørelse af afgørelsen i en sag mod en meget omtalt person. Kritikken blev nok udløst af, at kritikerne mente, at SKAT burde have givet retten meddelelse om den nye praksis eller have trukket sagen. Skatteministeren meddelte, at han havde besluttet at nedlægge den afdeling med 200 ansatte som beskæftigede sig bl.a. med disse sager. Professor i skatteret Jan Pedersen har i SR-SKAT 2013.147 ff. gennemgået bl.a. sagen med fotomodellen. Han oplyser, at SKAT i Projekt Credit Card undersøgte 400 sager. Der blev kun rejst sigtelse i 34 sager og alene tiltale med påstand om frihedsstraf i 4, heraf sagen mod fotomodellen. Komplekset belyser på udmærket vis, hvor svært det er at føre disse sager. Artiklen belyser måske også, at den offentlige forargelse over SKAT's sagsbehandling ikke var ganske begrundet. Om fotomodelsagen anfører Jan Pedersen, at resultatet blev, »at indkomster på mere end 13,8 mio. kr. hverken beskattes i Danmark, USA eller andetsteds og at dette skyldes en nøje skatteplanlægning «.

Der foregår for tiden et arbejde i EU med henblik på at fremskaffe kontroloplysninger fra lande, som ellers har været meget lidt interesseret i et samarbejde.

Ikke alene er sagerne om skattestrafferet for anklagemyndigheden svære at føre i retten, men det er nok også meget svært at mobilisere nogen velvilje for disse sager hos politikerne, som ellers ønsker en meget hård kurs over for kriminelle. Måske er der en ændret opfattelse på vej?

\section{Note}

1. Gorm Toftegaard Nielsen er professor i strafferet og straffeproces ved Århus Universitet, medlem af Straffelovrådet, Retsplejerådet og dommer i Den Særlige Klageret. 


\section{Øvrig litteratur}

Jan Pedersen: Skatte og afgiftsstrafferet, 2009

Lasse Lund Madsen: Strafbar medvirken i erhvervsforhold, 2009

Lasse Lund Madsen: Skattesvig i dansk ret i Økonomisk kriminalitet, nordiske perspektiver, i Nordisk Samarbejdsråd for kriminologi, 2010

Gorm Toftegaard Nielsen: Skattestrafferet - Ny vin på gamle flasker i Festskrift til Jan Pedersen, 2011, s. 359 ff. 